\title{
Material
}

\section{The language of midwifery and perinatal care: a quantitative analysis}

\author{
Yoko CHIBA $^{* 1}$, Neil MILLAR ${ }^{* 2}$, Brian BUDGELL*3
}

\begin{abstract}
Purpose

No quantitative information exists concerning the language of midwifery and perinatal care. To characterize the language learning burden placed on someone entering this area of health care, especially someone whose first language is not English, a study was undertaken of the lexical and syntactical features of a corpus of the literature of midwifery and perinatal care.
\end{abstract}

Methods

A corpus was created consisting of articles from 5 leading journals dealing with midwifery and perinatal care published from January to December in 2005. Keywords were identified by comparison with a corpus of general English and a corpus of the public health literature. Additionally, commonly recurring phrases were identified, and measures of readability were calculated.

Results

It was possible to identify 3,590 key words, including 242 highly prevalent core terms, and several phrases which have particular importance within the domain of midwifery and perinatal care. The vocabulary and phraseology suggest that the literature focuses on the interaction of mother, child and care-giver, processes related to birth and the importance of holistic care. Anatomical and pathological terms are uncommon. On average, the readability of the literature was appropriate for English speaking college graduates, with an average Flesch Reading Ease of 30.7. Conclusions

Using statistical methods, it was possible to identify a core vocabulary which had particular importance to and was highly prevalent in the literature of midwifery and perinatal care. The language of midwifery and perinatal care is distinct from general English, and more closely related to the language of public health. It is important to note that the language of midwifery and perinatal is relatively accessible if approached in a targeted fashion. It would appear that a high level of fluency in the literature of midwifery and perinatal care is achievable independent of high fluency in general English. However, this hypothesis remains to be tested with language learners.

Keywords: English, corpus, midwifery, perinatal care, language, education

\section{Introduction}

Biomedical and health education, research and practice occur in an increasingly globalized environment which presents the need for communications across national, cultural and linguistic boundaries. Improved communications facilitate policy implementation, clini- cal care, research collaborations and the dissemination of new knowledge to undergraduate and professional stakeholders. Thus, enhanced understanding of the lingua franca of biomedicine and health - what some would call "biomedical English" - would have considerable benefits for members of the biomedical and health communities, and for those they serve.

\footnotetext{
${ }^{{ }^{1}}$ Human Health Sciences Course, Graduate School of Medicine, Kyoto University, Kyoto, Japan

${ }^{* 2}$ Department of Linguistics and English Language, Lancaster University, Lancaster, U.K.

${ }^{\star 3}$ Canadian Memorial Chiropractic College, Toronto, Canada
} 
However, despite the enormous amount of research which is published in the language(s) of biomedicine and health, very little quantitative research is published about our shared language. Concerning the language of midwifery and perinatal care, no quantitative information exists. Therefore, as part of a wider project exploring the languages of a range of disciplines, the present study was undertaken to characterize the written language associated with midwifery and perinatal care. In particular, this study focused on the language of scholarly publication which would be an important medium for communicating new knowledge to students, educators, researchers and practitioners. As with parallel studies in biomedical and health linguistics, the present investigation was directed towards identifying the domain-specific characteristics of the language used in leading research publications in the field. It has previously been demonstrated that the lexical and syntactical features of nursing (Budgell, Miyazaki, O’Brien, et al., 2007) and public health (Millar \& Budgell, 2008) are indeed distinct from those of general English. Apart from their specific technical vocabularies, it is apparent that there are differences in grammatical conventions and even patterns of discourse. In general, the biomedical and health literature is characterized by low indices of readability, indicating the use of longer words and more complex sentence structures, including a high prevalence of sentences written in the passive voice (Millar $\&$ Budgell, 2008). Particular linguistic choices may also reflect the distinctive cultures of the respective disciplines and professional groups, including biases (in the scientific sense) which may not be explicitly recognized by those who create and consume the literature.

In this study, the lexical and syntactical features of the literature of midwifery and perinatal care were examined with reference to general English and a previous analysis of the language of public health. In part, these comparisons provide some measure of the language learning burden placed upon someone entering the discipline of midwifery and perinatal care with knowledge only of general English, or with knowledge of the language of a related discipline such as public health.

\section{Methods}

\section{Corpus development}

For the purposes of this study a corpus was created consisting of research articles, editorials, commentaries and reviews from 5 major journals dealing with midwifery and perinatal care (Table 1). The term "corpus" refers to a body of language selected and ordered according to specific linguistic criteria in order to be used as a representative sample of the target literature (McEnery, Tono, \& Xiao, 2006). The journals chosen for this corpus were selected because they were readily available in electronic form and, within the domain of midwifery and perinatal care, were the journals with the highest impact factors. The corpus of midwifery and perinatal care, referred to hereafter as the MPC corpus, included all issues published by these journals in 2005, the year which was also used for the nursing and public health corpora. Table 1 shows the number of tokens (the total word count, in the terminology of linguists), and number of types (different words, irrespective of number of occurrences) gathered from each journal.

\section{Corpus comparison}

The methodology employed in this study, as de-

Table 1 Composition of the corpus of MPC

\begin{tabular}{lccr}
\hline \multicolumn{1}{c}{ Journal (2005 impact factor) } & Papers & Tokens & Types \\
\hline Birth (1.836) & 42 & 125,202 & 7,292 \\
J Midwifery Womens Health (0.758) & 96 & 276,350 & 12,970 \\
J Obstet Gynecol Neonatal Nurs (0.846) & 90 & 305,599 & 12,705 \\
J Perinat Neonatal Nurs (0.654) & 48 & 137,852 & 9,429 \\
Midwifery (0.746) & 36 & 166,867 & 8,286 \\
\hline \multicolumn{1}{c}{ Total } & 312 & $1,011,870$ & 23,316 \\
\hline
\end{tabular}

* The total number of types for the entire corpus is not the sum of the numbers for each individual journal because the most common types are repeated from journal to journal. 
scribed previously (Millar \& Budgell, 2008), involved first archiving the target manuscripts as XML (Extensible Markup Language) documents. Using the software WordSmith 5.0 Tools (Oxford University Press, Oxford), the MPC corpus was compared to two reference corpora, a corpus of general English, as described below, and the corpus of Public Health (Millar \& Budgell, 2008). The reference corpus of general English used in this study is a subcorpus of the American National Corpus (Linguistic Data Consortium, Philadelphia) comprising 3,625,687 tokens (the total word count) from issues of the New York Times published in 2002. We refer to this as the NYT corpus. The Public Health Corpus consists of 1,921,278 tokens (the total word count) with 47,678 types (different words) from the volumes of 4 major public health journals published in 2005. This is referred to as the $\mathrm{PH}$ corpus.

\section{Identification of keywords}

As this study was directed towards the identification of the technical vocabulary which might confront a learner, prior to comparison with the NYT and PH corpora, a stop list, based on that of van Rijsbergen (1979), was used to filter out so-called function words such as prepositions, pronouns and articles. Furthermore, a threshold of 10 occurrences in the total MPC corpus (i.e. greater than 1 occurrence per 100,000 tokens) was set in order eliminate rare words from the analysis, as such words might have little impact on language learning burden.

Subsequently, keywords in the MPC corpus were calculated by comparison to (i) the NYT corpus, and (ii) the PH corpus. In corpus linguistics, keywords are those words which occur in a corpus more frequently than would be expected by chance when compared to a larger reference corpus (Baker, Hardie, \& McEnery, 2006). The degree to which a type is over-represented in a target corpus in comparison to a reference corpus, the 'keyness' of a word, is measured by log-likelihood - a statistic which, similar to chi-squared, compares observed and expected values for two data sets but does not make assumptions of normal distribution (see Dunning, 1993). As is conventional, a threshold of 15.13 was taken to indicate that a type occurred significantly more often in the MPC corpus (Rayson, Berridge, \&
Francis, 2004).

Additionally, dispersion of keywords was measured according to 2 standards: how many of the five journals the type appeared in and how many of the total number of journal articles (out of 312 articles) the type appeared in. This was done because any given type may be over-represented in a target corpus due to highly frequent use in only one or several articles. Thus, such a type may not be generally of importance in that biomedical or health domain. To draw an example from the MPC corpus, the type SARS (Severe Acute Respiratory Syndrome) was highly over-represented (frequency $=133$; keyness $=389.03$ ) and therefore would appear to have special significance in this domain. However, this is deceptive as the disease had not been described in 2002 and so it did not appear at all in the NYT corpus. Furthermore, that all 133 occurrences of the type SARS were within 1 article in a single journal in our corpus verifies that the type does not have any particular nuance in the domain of midwifery and perinatal care. Thus, dispersion, which measures how broadly a type appears across the entire corpus, provides an important supplementary measure of the role that a type plays in the technical vocabulary of a specific domain.

Keywords were classified according to whether they occurred on either of two external word lists: (i) the two thousand most common word families in the English language, also known as the General Service List (GSL) (West, 1953); and (ii) the Academic Word List (AWL) (Coxhead, 2000), the approximately 570 word families commonly encountered in academic environments. A word family is a group of words all derived from one root word. Hence, for example, "woman, women, women's..." would constitute one word family. Keywords which did not occur on either of the two external word lists are referred to as "off-list".

\section{Identification of key phrases}

In addition to identification of individual keywords, the MPC corpus was searched with the software WordSmith Tools 5.0 (Oxford University Press, Oxford) in order to identify commonly recurring phrases, referred to as n-grams, where " $n$ " represents the number of words in the phrase. 


\section{Calculation of readability}

Finally, 10,000 word samples of text from each of the 5 component journals were analyzed using the statistics function in MS Word 2008 V12.1.0 (Microsoft Corporation) in order to determine readability indices. These samples commenced with the first article recovered for each journal and proceeded forward through the journal's contents, to be truncated at the end of the sentence containing the 10,000th word. Thus, the samples should not be regarded as random.

A number of formulae are available to calculate the relative readability of texts, and these readability indices are often based on word and sentence length. The measures used in this study are (i) average number of words (tokens) per sentence, (ii) average number of characters per word (token), (iii) proportion of sentences written in the passive voice, and (iv) Flesch Reading Ease which is calculated from number of words per sentence, syllables per word and characters per word (Flesch, 1948). A lower index of (i), (ii) and (iii) and a higher index of Flesch Reading Ease signal that the text is easier to read.

\section{Results}

\section{Identifying keywords in comparison to general English}

Comparison of the MPC corpus to the NYT corpus yielded a list of 3,590 types which were over-represented (log likelihood $>15.13)$ relative to their prevalence in general English - that is to say, these 3,590 words occurred much more often in midwifery and perinatal care than would be expected from their prevalence in general English. Eliminating types which occurred with a frequency of less than approximately 1/100,000 tokens (i.e. less than 10 times in the MPC corpus) reduced the list to 3,124 types. Taking into account low dispersion by removing types which occurred in only 1 out of the 5 component journals in the MPC corpus reduced the list to 1,669 types. Further removing types which occurred in less than $5 \%$ of articles (i.e. 15 or fewer out of the 312 articles in the corpus) reduced the list to 1,108 types. These keywords surpassing a set, albeit arbitrary, threshold for dispersion are referred to herein as core words.
Of these core words, 335 were from among the 1,000 most common words in the English language, and 141 were from among the second 1,000 most common words. Thus, 476 of the types (words) were from the GSL. An additional 390 types (words) were from among the word families of the AWL. The remaining 242 core words were off-list, neither from the GSL or AWL. Table 2 presents the 30 most highly over-represented core words belonging to the GSL, AWL or being off-list. These words are ranked according to declining frequency (Freq.) in the MPC corpus. In Table 2, Keyness indicates a measure of how over-represented the word is in the MPC corpus based on its prevalence in general English. Dispersion (Disp.) shows how many articles (out of a total of 312) and how many journals (out of 5) the word appeared in. The complete list of keywords (not just the top 30 shown in Table 2) is archived at http:// bmhlinguistics.org/joomla2/language-of-midwifery.

GSL and AWL words alone constituted 85.55\% of the MPC corpus. Combining the one thousand, two thousand and three thousand most prevalent offlist words with the GSL and AWL provided 94.84\%, $96.40 \%$ and $97.23 \%$ coverage, respectively, of all words in the corpus. In other words, if a reader knew the 2,000 GSL words, the 570 word families of the AWL and an additional 3,000 key words, they would be able to read $97.23 \%$ of the words in our sampling of the midwifery and perinatal care literature.

The core vocabulary of midwifery and perinatal care, not surprisingly, appears to be marked by a high prevalence of types referring to the mother, child, caregiver and the interactions between these three (Table 2). Among the 100 most prevalent keywords, there was only one anatomical term (\#51 breast) and only three terms which might have a pathological nuance (\#41 pain, \#55 depression, \#94 stress). Keywords also illuminate qualitative differences between domains. Discourse in midwifery and perinatal care is characterized by a greater prevalence of words relating to the holistic, social and emotive aspects of care - for example, family, bonding, feelings, anxiety, quiet, relaxation and experience were all keywords.

The diminishing coverage provided by adding offlist keywords is represented graphically in Figure 1. To 
achieve $100 \%$ coverage of the corpus required the GSL, the AWL plus an additional 17,148 off-list words. Adding the 242 off-list core words (i.e. off-list words which are statistically significant and dispersed throughout the MPC corpus) to the GSL words and the AWL words in- creased coverage to $92.46 \%$ of all words in the corpus. This demonstrates that the most efficient approach for a learner to increase their literacy in midwifery and perinatal care is to begin by learning these 242 core words.

Table 2 Keywords in comparison to NYT corpus, ordered against external word lists and ranked by number of occurrences

\begin{tabular}{|c|c|c|c|c|c|c|c|c|c|c|c|}
\hline \multicolumn{4}{|c|}{ GSL } & \multicolumn{4}{|c|}{ AWL } & \multicolumn{4}{|c|}{ OFF-LIST } \\
\hline Keyword & Freq. & Keyness & Disp. & Keyword & Freq. & Keyness & Disp. & Keyword & Freq. & Keyness & Disp. \\
\hline women & 8094 & 16215.54 & $266 / 5$ & significant & 913 & 1397.71 & $212 / 5$ & pregnancy & 2116 & 5807.89 & $195 / 5$ \\
\hline care & 5290 & 10947.42 & $298 / 5$ & factors & 882 & 1890.79 & $187 / 5$ & infant & 1552 & 4216.41 & $170 / 5$ \\
\hline study & 3283 & 6065.87 & $251 / 5$ & period & 791 & 967.25 & $189 / 5$ & midwifery & 1488 & 4353.94 & $103 / 5$ \\
\hline support & 2100 & 3129.95 & $232 / 5$ & outcomes & 786 & 2205.63 & $191 / 5$ & postpartum & 1475 & 4299.82 & $129 / 5$ \\
\hline risk & 1492 & 2082.18 & $216 / 5$ & process & 751 & 696.66 & $165 / 5$ & maternal & 1284 & 3635.81 & $171 / 5$ \\
\hline hospital & 1412 & 2482.38 & $182 / 5$ & positive & 696 & 1123.65 & $145 / 5$ & breastfeeding & 1020 & 2968.86 & $62 / 5$ \\
\hline reported & 1336 & 1864.82 & $214 / 5$ & intervention & 665 & 1691.40 & $118 / 5$ & pregnant & 815 & 1900.46 & $136 / 5$ \\
\hline nurses & 1291 & 3358.63 & $167 / 5$ & available & 619 & 427.61 & $185 / 5$ & midwife & 703 & 2030.18 & $98 / 5$ \\
\hline studies & 1217 & 2146.28 & $215 / 5$ & professional & 599 & 775.51 & $150 / 5$ & childbirth & 568 & 1625.69 & $108 / 5$ \\
\hline education & 1201 & 1693.91 & $187 / 5$ & status & 574 & 913.23 & $160 / 5$ & $\mathrm{n}$ & 533 & 70.84 & $106 / 5$ \\
\hline delivery & 1103 & 2622.42 & $183 / 5$ & issues & 557 & 377.67 & $176 / 5$ & newborns & 468 & 1307.83 & $59 / 5$ \\
\hline treatment & 988 & 1505.09 & $142 / 5$ & identified & 531 & 811.22 & $176 / 5$ & vaginal & 423 & 1042.26 & $89 / 5$ \\
\hline based & 969 & 471.13 & $245 / 5$ & primary & 499 & 777.77 & $159 / 5$ & diagnosis & 415 & 991.04 & $95 / 5$ \\
\hline age & 964 & 1090.48 & $200 / 5$ & specific & 498 & 727.91 & $185 / 5$ & scores & 414 & 710.16 & $81 / 5$ \\
\hline groups & 949 & 1042.35 & $189 / 5$ & focus & 485 & 514.77 & $149 / 5$ & cancer & 404 & 207.56 & $41 / 5$ \\
\hline experience & 923 & 1148.85 & $184 / 5$ & appropriate & 470 & 828.99 & $186 / 5$ & antenatal & 401 & 1173.01 & $64 / 5$ \\
\hline patient & 904 & 1815.12 & $138 / 5$ & assessment & 464 & 972.31 & $135 / 5$ & $\mathrm{acnm}$ & 373 & 1091.09 & $29 / 2$ \\
\hline screening & 895 & 1955.24 & $87 / 5$ & access & 449 & 422.08 & $133 / 5$ & emotional & 355 & 522.56 & $92 / 5$ \\
\hline important & 886 & 638.43 & $232 / 5$ & professionals & 439 & 899.84 & $122 / 5$ & postnatal & 349 & 1020.88 & $65 / 5$ \\
\hline related & 877 & 1444.30 & $230 / 5$ & significantly & 433 & 756.41 & $133 / 5$ & interviews & 332 & 461.61 & $70 / 5$ \\
\hline work & 852 & 16.91 & $181 / 5$ & community & 431 & 186.88 & $114 / 5$ & abuse & 329 & 206.96 & $41 / 5$ \\
\hline high & 843 & 71.30 & $223 / 5$ & potential & 431 & 307.83 & $170 / 5$ & counseling & 301 & 619.42 & $66 / 4$ \\
\hline weight & 838 & 1514.95 & $94 / 5$ & communication & 400 & 886.36 & $93 / 5$ & questionnaire & 299 & 798.03 & $79 / 5$ \\
\hline pain & 835 & 1543.15 & $94 / 5$ & survey & 387 & 497.53 & $100 / 5$ & african & 278 & 230.49 & $50 / 5$ \\
\hline findings & 818 & 1790.53 & $198 / 5$ & strategies & 382 & 710.53 & $108 / 5$ & physician & 276 & 554.29 & $94 / 5$ \\
\hline results & 809 & 1066.46 & $214 / 5$ & approach & 379 & 277.10 & $132 / 5$ & adolescents & 256 & 694.81 & $31 / 4$ \\
\hline low & 787 & 522.15 & $179 / 5$ & variables & 371 & 1004.83 & $97 / 5$ & reproductive & 255 & 536.31 & $68 / 5$ \\
\hline associated & 772 & 1438.53 & $197 / 5$ & perceived & 369 & 721.71 & $94 / 5$ & childbearing & 246 & 707.08 & $81 / 5$ \\
\hline number & 758 & 344.24 & $219 / 5$ & labour & 355 & 1038.44 & $29 / 3$ & therapy & 240 & 157.16 & $59 / 5$ \\
\hline life & 729 & 32.26 & $171 / 5$ & identify & 350 & 533.68 & $152 / 5$ & versus & 232 & 441.42 & $88 / 5$ \\
\hline
\end{tabular}

Frequency (Freq.): the number of occurrences in the MPC corpus

Keyness: the degree to which a type is over-represented in a targeted corpus (MPC corpus) in comparison to a reference corpus (NYT corpus) Dispersion (Disp.): the number of articles/the number of joumals in which type occurred

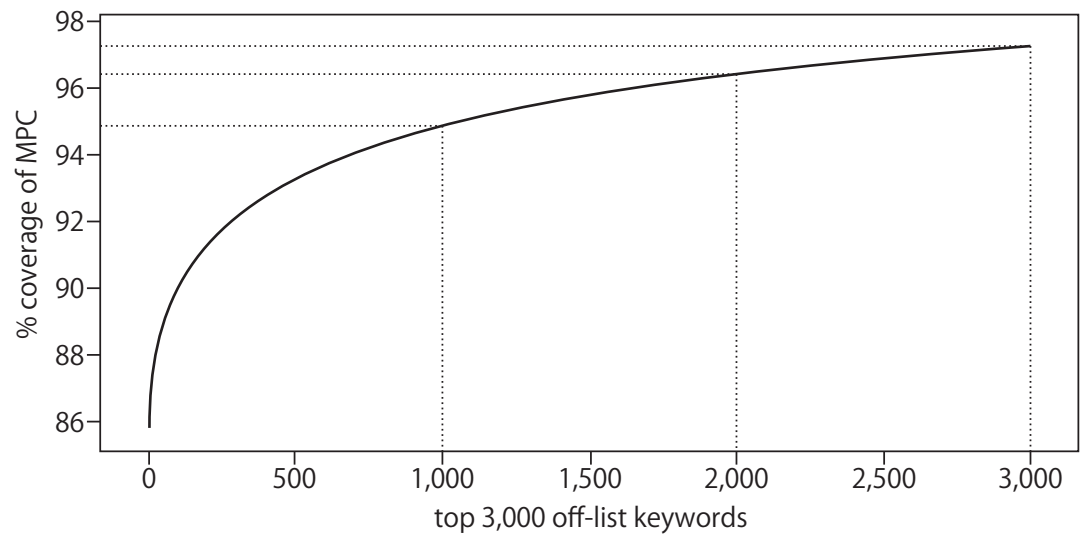

Fig. 1 Percentage coverage of the MPC corpus provided by the top three thousand off-list keywords 


\section{Identifying keywords in comparison to Public Health}

Comparison with the $\mathrm{PH}$ (Public Health) corpus revealed 1,841 types which were over-represented in the MPC corpus. Eliminating types which occurred with a frequency of less than approximately 1/100,000 tokens (i.e. less than 10 times in the MPC corpus) reduces the list to 1,722 types. Taking into account dispersion by removing types which occurred in only 1 out of the 5 component journals in the corpus reduces the list to 770 types. Further removing types which occurred in less than $5 \%$ of articles (i.e. 15 or fewer of the 312 articles in the corpus) reduces the list to 410 types. Of these types, 205 were from among the GSL, 80 were from the AWL, and a mere 125 were off-list. In comparison to the $\mathrm{PH}$ corpus, words which are underrepresented in midwifery and perinatal care (so-called 'negative' keywords) are strongly associated with logic, reason and the scientific method - for example, subjects, costs, data, statistical, control and results. This observation is congruent with view that midwifery is a "science that emphasizes the uniqueness of each nurse-client encounter" (Hunter, 2006).

\section{Identifying key phrases}

Counting only those n-grams (phrases) which occurred more than 5 times in the MPC corpus, there were a total of 91 7-grams, 255 6-grams, 891 5-grams, 3,559 4-grams and 12,829 3-grams. The 5 most commonly recurring meaningful n-grams in each cohort are listed in Table 3, wherein the symbol \# is used to represent a number. In Table 3, n-grams (phrases) are listed in descending order of the number of times (Freq.) that they occurred in the entire corpus. Also the number of articles (Texts) that they occurred in is listed.
Table 3 Five most commonly recurring meaningful 7-grams, 6-grams, 5-grams, 4-grams and 3-grams

\begin{tabular}{lcc}
\hline 7-grams & Freq. & Texts \\
\hline the purpose of this study was to & 35 & 28 \\
the American college of obstetricians and gynecologists & 32 & 26 \\
the purpose of this article is to & 30 & 29 \\
the centers for disease control and prevention & 18 & 14 \\
between the ages of \# and \# & 16 & 13 \\
the aim of this study was to & 15 & 12 \\
\hline 6-grams & Freq. & Texts \\
\hline the American college of nurse midwives & 85 & 37 \\
the American college of nurse midwifery & 36 & 7 \\
department of health and human services & 29 & 21 \\
there were no significant differences in & 19 & 11 \\
the first \# months of life & 18 & 8 \\
\hline 5-grams & Freq. & Texts \\
\hline \# p less than \# & 134 & 39 \\
ranged from \# to \# & 82 & 38 \\
between \# and \# weeks & 43 & 25 \\
the findings of this study & 37 & 23 \\
the second stage of labor & 34 & 8 \\
\hline 4-grams & Freq. & Texts \\
\hline in the United States & 332 & 131 \\
at the time of & 137 & 75 \\
\# to \# weeks & 111 & 47 \\
on the basis of & 102 & 61 \\
at \# weeks postpartum & 379 & 10 \\
\hline 3-grams & 369 & 140 \\
\hline as well as & 340 & 110 \\
the use of & 230 & 91 \\
in this study & 228 & 107 \\
in table \# & & \\
\hline
\end{tabular}

\section{Readability indices}

Table 4 lists the measures of readability of 10,000 token samples from each of the 5 journals. The average index of each measure is $22.4 \pm 1.6$ for the number of words (tokens) per sentence and $5.4 \pm 0.2$ for the number of characters per word (token). Thus, the MPC corpus had a mean Flesch Reading Ease index of $30.7 \pm 5.0$. Use of the passive voice may also contribute to sentence complexity, and in samples from this corpus an average of $29.4 \pm 6.0 \%$ of the sentences employed the passive voice.

Table 4 Journal readability indices

\begin{tabular}{lcccc}
\hline \multicolumn{1}{c}{ Journal } & Words/Sentence & Characters/Word & Passive & Flesch Reading Ease \\
\hline Birth & 23.7 & 5.5 & $30 \%$ & 25.8 \\
J Midwifery Womens Health & 19.9 & 5.1 & $19 \%$ & 36.7 \\
J Obstet Gynecol Neonatal Nurs & 23.7 & 5.3 & $34 \%$ & 33.5 \\
J Perinat Neonatal Nurs & 21.8 & 5.5 & $29 \%$ & 26.7 \\
Midwifery & 22.9 & 5.5 & $35 \%$ & 30.6 \\
\hline Mean (S.D.) & $22.4(1.6)$ & $5.4(0.2)$ & $29.4 \%(6.0 \%)$ & $30.7(5.0)$ \\
\hline
\end{tabular}




\section{Discussion}

This study analyzed a representative sample of the literature of midwifery and perinatal care in order to characterize the lexical and syntactical features of the domain. Comparison to a corpus of general English (the NYT corpus) identified a core vocabulary which would present an important learning burden to those entering the field. Comparison of the MPC corpus with a corpus of the public health literature (the PH corpus) identified a much smaller number of novel words which would be necessary for effective communications between these two fields. Readability indices were calculated for text samples drawn from each of the 5 journals, and these measures also provide some insight into the accessibility of the literature.

Comparison of the MPC corpus keywords to external word lists provides some measure of the accessibility of these terms. The two external word lists used in this study were (i) the General Service List - the 2,000 most common word families in the English language and (ii) the Academic Word List (AWL) of Coxhead (2000) - the list of 570 word families commonly encountered in academic environments. When keywords from the target corpus occur among the GSL, it is possible that their meanings within midwifery and perinatal care can be easily derived as result of frequent exposure to their use in general English (Chung \& Nation, 2004). Similarly, keywords that occur in the AWL are likely to be more accessible as a result of their widespread use in academic discourse. Of course, this is not invariably the case, since high prevalence within the corpus may also signal a special nuance within the domain of midwifery and perinatal care. Examples of such keywords from the GSL (with their nuances in the MPC corpus) are failure (interrupted labour) and delivery (the child birth) and, in the AWL, formula (milk substitute) and labour (the process of child birth). Notwithstanding this caveat, progression from the GSL to the AWL, and then to off-list words, on the whole marks a clear movement away from vocabulary which is widely used in general English, and therefore off-list words are particularly likely to be technical and unfamiliar to those without specialized training. Thus, it is these terms, for example, postpartum, antenatal, gestational, episiotomy and analgesia (all "off-list" words), which are likely to provide the greatest language learning burden for those entering the field.

The criteria used in this study to identify core words, frequency $>1 / 100,000$ tokens, and dispersion $>5 \%$ of articles and $>1$ of 5 component journals, are arbitrary but permit meaningful comparisons to previous studies (Budgell, Miyazaki, O'Brien et al., 2007; Millar $\&$ Budgell, 2008). This approach confirms the existence of a core vocabulary which distinguishes the literature of midwifery and perinatal care from general English. It also confirms that the language learning burden would be smaller for a person with a working knowledge of, for example, the language of public health. At present, adequately large comparison corpora for other disciplines, such as nursing, are not available.

The current approach to language analysis also provides a context, permitting comparison of the total vocabulary required in order to be literate in the domain of midwifery and perinatal care with the vocabulary required to function in general English. In order to read fluidly across the breadth of general English and infer meanings of unknown types (words), it is estimated that one needs to understand approximately $95 \%$ of the tokens within a text, and this, in turn, requires a vocabulary of approximately 15,000 types (Hirsh \& Nation, 1992; Laufer, 1992). On the other hand, in order to achieve the same $95 \%$ coverage in the language of midwifery and perinatal care, rather than general English, one would require knowledge of the 2,000 word families of the GSL, the 570 word families of the AWL, plus a knowledge of a set of core words specific to midwifery and perinatal care - off-list keywords. The addition of the 1,000 most prevalent off-list words provides coverage of $94.84 \%$ which is approximately the threshold for fluid reading in general English. Thereafter, adding successive thousands of off-list words results in only incremental improvements in literacy, since these additional off-list words occur so seldom (see Figure 1). The addition to the GSL and AWL of the 242 off-list core words identified in this study would provide $92.46 \%$ coverage of all text in the corpus. All of these off-list core words fall within the 1,000 off-list words neces- 
sary to raise text coverage to the $95 \%$ threshold. This set of 242 core words (words with a statistically significant frequency and wide dispersion) therefore represents vocabulary which is central to the literature of midwifery and perinatal care, and demonstrates that in order to achieve functional literacy in the language of midwifery and perinatal care, targeting a core vocabulary, such as we have identified, is remarkably more efficient than taking an untargeted approach.

Fluency requires not just a knowledge of isolated words but also an understanding of how words are combined into meaningful expressions (Nation, 2001). This study identified phrases which recur frequently and thereby provide a fixed context for certain core words. These phrases provide authentic and meaningful exemplars for language learners and teachers. The more commonly recurring phrases in the MPC corpus particularly refer to organizational units within the domain and related disciplines, and, of course, procedures related to research (Table 3). Basic life sciences vocabulary related to anatomy and pathology was not well represented.

Concerning the overall accessibility of the literature, in comparison to general English, writing in midwifery and perinatal care appears to involve words with more characters $(5.4 \pm 0.2$ characters per word) and sentences with more words (22.4 \pm 1.6 words per sentence) (Table 4). Since writings in the range of 0 to 30 on the Flesch Reading Ease scale are thought to be appropriate for American college graduates (Flesch, 1948), the literature of midwifery and perinatal care, with a Flesch Reading Ease of 30.7, appears appropriate for readers at approximately the level of college graduation. It is somewhat more readable than the literature of public health, with a Flesch Reading Ease of 23.2 (Millar \& Budgell, 2008). Use of the passive voice may also contribute to sentence complexity, and in the MPC corpus an average of $29.4 \pm 6.0 \%$ of the sentences employed the passive voice. The percentage is a little higher than the average of the PH corpus $(26.0 \pm 4.0 \%)$ (Millar \& Budgell, 2008).

\section{Conclusion}

The language of midwifery and perinatal care is distinct from general English, and more closely related to the language of public health. The language of midwifery and perinatal care has a distinctive core vocabulary and is characterized by certain recurrent phrases. The vocabulary and phraseology suggest that the literature focuses on the interaction of mother, child and care-giver, processes related to birth and the importance of holistic care and client-care-giver interactions. Anatomical and pathological terms are uncommon.

Given the ongoing globalization of health care education, research and practice, including increasing migration of health care providers, it is important to note that the language of midwifery and perinatal care is relatively accessible if approached in a targeted fashion. It would appear that a high level of fluency in the literature of midwifery and perinatal care is achievable independent of high fluency in general English. However, this hypothesis remains to be tested with language learners.

\section{Acknowledgment}

This work was partly supported by a grant from the Japan Academy of Midwifery, Tokyo, Japan.

\section{References}

Baker, P., Hardie, A., McEnery, T. (2006). A glossary of corpus linguistics, Edinburgh: Edinburgh University Press.

Budgell, B., Miyazaki, M., O'Brien, M., Perkins, R., \& Tanaka, Y. (2007). Developing a corpus of the nursing literature: a pilot study, Japan Journal of Nursing Science, 4, 21-25.

Chung, T.M., Nation, P. (2004). Identifying technical vocabulary, System: An International Journal of Educational Technology and Appoied Linguistics, 32, 251-263.

Coxhead, A. (2000). A new academic word list, TESOL Q, 34, 213-238.

Dunning, T. (1993). Accurate methods for the statistics of surprise and coincidence, Computational Linguistics, 19(1), 61-74.

Flesch, R. (1948). A new readability yardstick, The Journal of Applied Psychology, 32, 221-233.

Hirsh, D., Nation, P. (1992). What vocabulary size is needed to read unsimplified texts for pleasure? Reading in a Foreign Language, 8(2), 689-696.

Hunter, L.P., (2006). Women give birth and pizzas are delivered: language and western childbirth paradigms, The Journal of 
Midwifery \& Women's Health, 51, 119-124.

Laufer, B. (1992). How much lexis is necessary for reading comprehension? In Arnaud PJ, Béjoint H. (Eds.), Vocabulary and applied linguistics (pp. 126-132), London: Macmillan.

McEnery, T., Tono, Y., Xiao, Z. (2006). Corpus-based language studies: an advanced resource book, London: Routledge.

Millar, N., Budgell, B. (2008). The language of public health- a corpus based analysis, The Journal of Public Health, 16(5), 369-374.

Nation, ISP. (2001). Learning vocabulary in another language, Cambridge: Cambridge University Press.
Rayson, P., Berridge, D., Francis, B. (2004). Extending the Cochran rule for the comparison of word frequencies between corpora, Paper presented at the 7th International Conference on Statistical Analysis of Textual Data, 10-12 March, Louvain-la-Neuve.

Van Rijsbergen C.J. (1979). Information retrieval (2d ed), London: Butterworths.

West, M.P. (1953). A general service list of English words: with semantic frequencies and a supplementary word-list for the writing of popular science and technology, London: Longmans Green. 


\title{
助産学・周産期ケア分野における英語：量的分析
}

\author{
千 葉 陽 子*1, Neil MILLAR*2, Brian BUDGELL*3 \\ ${ }^{* 1}$ 京都大学大学院医学研究科人間健康科学系専攻 \\ ${ }^{* 2}$ Department of Linguistics and English Language, Lancaster University, Lancaster, U.K. \\ ${ }^{* 3}$ Canadian Memorial Chiropractic College, Toronto, Canada
}

抄 録

\section{目 的}

助産学・周産期ケア分野で用いられる言語 (英語を母語としない者にとっては「英語」) は今まで量的 に分析されておらず，これに関する情報もない。この分野で特に母語が英語でない者にとつての言語学 習負担を明らかにするため, 本研究では助産学・周産期ケア分野の英語論文のコーパス (総語彙集) を 作成し，語彙や文章構造の特徵を分析した。

\section{方 法}

2005年1月から 12 月に発行された助産学・周産期ケア分野の英語雑誌の中から主要 5 誌を選び，これ らの中の論文で用いられた英語をもとにコーパスを作成した。そして，一般英語 (General English) お よび保健分野 (Public Health) の論文で用いられた英語との比較によりキーワードを抽出した。また頻 出熟語を抽出し，読みやすさ尺度を計算した。

\section{結 果}

助産学・周産期ケア分野で特に重要な英語として，頻出語彙 242 語を含む 3,590 語のキーワードと頻 出熟語を抽出した。抽出結果より, 当該分野の英語論文には母親・子供・ケア提供者間の関わり合い, 出産のプロセス，包括的ケアの重要性に関する語句がよく用いられていた。身体の名称や疾病に関する 用語の使用はあまり認められなかった。読みやすさ尺度に関する Flesch Reading Ease指数 (30.7) より, この分野の英語論文を読むには，平均的に，英語圈の大学卒業者程度の英語能力が必要であることが示 唆された。

\section{結 論}

量的分析によって, 助産学・周産期ケア分野の英語論文の中で核となる重要頻出語句を抽出すること ができた。当該分野の英語は，一般英語とは異なる点があり，保健分野の英語とはより密接に関係し合 つていた。量的分析の結果をもとに語句の焦点を絞って学習することで，助産学・周産期ケア分野の英 語は比較的習得しやすくなることが示され，一般英語の理解とはまた独立した形で，当該分野の英語を よりスムーズに理解することが可能であると示唆された。今後, 本研究で得られた仮説を検証していく 必要がある。

キーワード：英語，総語彙集，助産学，周産期ケア，言語，教育 